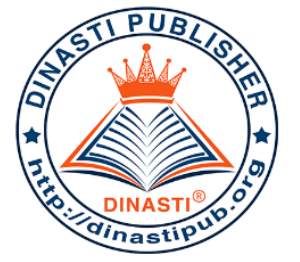

\title{
THE EFFECTIVENESS OF LEADERSHIP STYLE TO THE EMPLOYEE PERFORMANCE (THE STUDY ON EMPLOYEES IN ENGLISH LANGUAGE EDUCATION DEPARTMENT)
}

\author{
M. Daud Batubara ${ }^{1}$, Kasman $^{2}$, Roldan Caparino Cabiles ${ }^{3}$ \\ 1) STAIN Mandailing Natal, Panyabungan, Indonesia \\ ${ }^{2)}$ STAIN Mandailing Natal, Panyabungan, Indonesia \\ 3) Bicol University Open University,Legazpy, Philippines
}

\begin{tabular}{|c|c|}
\hline $\begin{array}{c}\text { ARTICLE INFORMATION } \\
\text { Received: } 24^{\text {th }} \text { July } 2020 \\
\text { Revised: } 12^{\text {nd }} \text { August } 2020 \\
\text { Issued: } 22^{\text {th }} \text { August } 2020 \\
\text { Corresponding author: Roldan } \\
\text { E-mail: } \\
\text { mdaudbatubara@ @stain-madina.ac.id } \\
\frac{\text { kasman@ @stain-madina.ac.id }}{\text { rccabiles@ @icol-u.edu.ph }}\end{array}$ & $\begin{array}{l}\text { Abstract: This study aims to determine the } \\
\text { effectiveness of leadership style to employee } \\
\text { performance (study on English language education } \\
\text { department). This study was quantitative research. } \\
\text { The data of collecting used questioner. The } \\
\text { population is seventeen and as sample. The } \\
\text { analysis data of technique descriptive analysis and } \\
\text { Likert scale. The result of this study shown that } \\
\text { The four variables (leadership style) have an } \\
\text { important influence to Y (employee performance). } \\
\text { This can be seen from sales above almost all } \\
\text { respondents answer strongly agree of category. } \\
\text { This means that leadership style has big influence } \\
\text { to employee performance in English Education } \\
\text { Language Department, State of Islamic (STAIN) } \\
\text { Mandaling Natal. } \\
\text { Keywords: Leadership Style, } \\
\text { Performance. }\end{array}$ \\
\hline
\end{tabular}

\section{INTRODUCTION}

An organization needs employees who have potential, knowledge, high skill and effort to optimally carry out all activities and objectives. Sholeha and Suzy (1996) explained that organization is a union of people whose businesses must be coordinated. They emphasized that teamwork on basics of division of labor is something that needs to be focused on. The role of leadership in organization or unit is very important to influence employees as members of the organization. Furthermore, Koesmono (2007:30) highlighted that the existence of leader in an organization brings organization to its intended goal. Each leader has a different leadership style to affect employees' performances in order to materialize the goals of an organization. There are four leadership styles in organization such 
as: (a) directive leadership style; (b) supportive leadership style; (c) participative leadership style; and (d) leadership oriented style (Robbins, 2007:448). These types of leadership are contributory to the success and development of the organization.

English Language Education Department is a unit that manages some of the activities in the University. Some of the activities that are managed by the University comprise the making of schedule and administration and so on. English Language Education is one of the program studies in State of Islamic (STAIN) Mandailing Natal that has 16 lecturers, one (1) secretary, and one (1) head of English Language Education. English Language Education Program envisions materializing its living mission and vision to capacitate its employees so that they would become potential individuals who do quality work with advanced skill and the like. To achieve its goal, there is a need to intensify the role of leadership to improve the quality of employees' performance in attaining its mission and vision.

Thus, this study on the Effect of Leadership Style on Employees' Performance is timely and relevant. This is a study on employees in English Language Education Department, State of Islamic (STAIN) Mandailing Natal.

\section{LITERATURE REVIEW}

A leader must involve all levels of organization and its members or the community should take an active role so they can give positive influence to reach a goal. According to Hasibuan (2007), leadership is a way to influence employee's behavior in order to work together and work productively in an organization. Further, Krietner and Kinicki (2005:249) expressed that leadership is a process of social influence where leader joins voluntary participation from subordinates to reach a goal. This means that leadership has a big influence to manage subordinates (employees) to reach mission and vision of a unit or an organization.

Leadership style is used by a leader in interacting with subordinates. Thoha (2007) explained that leadership style is a way by which a chairman uses in influencing employees so that they work well to reach a purpose. Leadership style is also a behavior or an action of leader in carrying out management work (Soekarjo, 2010). While Kartono (2002:62) said that leadership style is a leadership way in guiding his subordinates to do something. From these experts' explanation, it can be concluded that leadership style is the nature and behavior of a leader in guiding and influencing his employees to do work well. There are four leadership styles used by leaders to influence employees such as: 1) Directive leadership - the leader provides specific advice to group and establishes key rules; 2) Supportive leadership - the employee or group has a good relationship with the leader and shows sensitivity to the needs of members; 3) Participative leadership - the leader makes a decision on consultation with group members and shares information with group; and lastly 4) Leadership oriented - the leader faces members on challenge goals and pushes high performance and shows confidence in group's ability (Robbin. 2007).

The employee's performance plays an important role in the achievement of an organization's goal. According to Makunegara (2002), performance is the quality and quantity work that is achieved by an employee in carrying out his work responsibly and maximum level. 
In addition, Wirawan (2009) expressed that out produced by function or indicator of occupation or a profession within a certain time. The performance of a person towards achieving a goal in dependent on these elements: obstacles, initiatives, innovation, accuracy, outcome, attendance, attitude, teamwork, neatness, quality of work and so on (Siagian, 2006). With this, it is implied that an employee must meet all these elements to improve the local practices along governance in an organization to build significant relationship.

There are three factors that affect a performance. These are: 1) Individual ability - this includes talent, interest and personality factors; 2) Effort poured out - this pertains to motivation, work ethics and attendance; and, 3) Organization support - the company provides facilities for employees, example: training, development, equipment, technology, performance standard, management and co-workers (Mathis and Jackson, 2006).

The effect of leadership style on employees' performance is also explained by Robbins that leadership as ability to influence a group to reach goal (Robbins, 2007). This means that leadership style has influences employees' performance.

\section{RESEARCH METHODS}

This study utilized a quantitative research method incorporating the method of Singgarimbun and Effendi (1995). This used two variables namely Leadership style as independence $(\mathrm{X})$ while employee performance as dependence. This method employed data samples from a population and used a questionnaire as a tool to collect primary data in this study and then according Sugiyono (2011) said that questionnaire is the data collection techniques are done by giving a set of questions. According to Morissan (2012:19), population is collective subjects, variables, concepts, or phenomena, the population in this study was the 17 and they all are as sample this study. The analysis data used likert scale and descriptive analysis to know the effectiveness of leadership style to employee performance. This study was conducted on the $17^{\text {th }}$ of February 2020 until $30^{\text {th }}$ day of June 2020 at the English Language Education Department, State of Islamic (STAIN) Mandailing Natal.

\section{FINDINGS AND DISCUSSION}

\section{Findings}

This study was conducted in English Language Education of Department, State of Islamic (STAIN) Mandailing Natal, this started from February $17^{\text {th }} 2020$ until June $30^{\text {th }} 2020$. The sample used all population. The data of collecting used questionnaire that consists of leadership style and employee performance. To Leadership style consists of two questions in directive leadership, three questionnaires in supportive leadership, four questionnaires in participative leadership and two questionnaires in leadership oriented while to employee performance contents five questionnaires. The writers took all population as sample in English Language Education of Department, State of Islamic (STAIN) Mandailing Natal , the number of respondent are 17 people, the below table explained profile respondent :

Table 1. Respondent Criteria

\begin{tabular}{|c|c|c|}
\hline Criteria & Sub Criteria & Total \\
\hline Sex & Male & 4 \\
\hline & Female & 13 \\
\hline
\end{tabular}




\begin{tabular}{|c|c|c|}
\hline Respondent of Job Title & Sectary & 1 \\
\hline & Lecturer & 16 \\
\hline
\end{tabular}

\section{Discussion}

To know the effectiveness of leadership style to employee performance in English Language Education, State of Islamic (STAIN) Mandailing Natal, used descriptive analysis and formal scale Likert based on responding in questionnaires and then Likert scale answer forms included strongly agree, agree, doubt, disagree, and strongly disagree.

Formula: T x PN

$\mathrm{T}$ : The choice number of Respondent

Pn: The choice of Likert Score

Interpretation of Calculation Score

To get Interpretation score, the highest score (X) and the lowest score (Y) must be known for the assessment items using the formula below:

Y : The Highest Likert score $\mathrm{x}$ the number of respondent

$\mathrm{X}$ : The lowest Likert score $\mathrm{x}$ the number of respondent

The number of the highest score to item" strongly agree is $5 \times 17=85$, while the lowest of item score "strongly disagree is $1 \times 17=17$. This means that if the total of respondent's score is 85 so then the assessment of respondents' interpretation of the leadership style to employee performance was the result of value generated using the formula Index \%. We must also know interval and interpretation percent in order to know assignment. This interval formula below is $\mathrm{I}=100 /$ total score (Likert) so $100 / 5=20$. This is interval from the lowest $0 \%$ to the highest $100 \%$.

a. Assignment of Positive Questionnaire Intervals

- Number $0 \%-19,99 \%=$ Strongly Disagree

- Number 20\% - 39,99\% = Disagree

- Number $40 \%-59,99 \%$ = doubt

- Number $60 \%-79,99 \%$ = Agree

- Number $80 \%$ - 100\% = Strongly Agree

b. Assignment of Negative Questionnaire Intervals

- Number 0\% - 19,99\% : Strongly Agree

- Number 20\% - 39,99\%: Agree

- Number $40 \%$ - 59,99\% : doubt

- Number 60\% - 79,99\% : Disagree

- Number $80 \%$ - 100\% : Strongly Disagree (Darmadi,2011) 
This table below will explain result of this study:

Table 2. Result of Study

\begin{tabular}{|l|l|l|l|l|}
\hline No & Directive leadership of questionnaire & Score & Percent & Category \\
\hline 1. & $\begin{array}{l}\text { The leader in my place work fosters } \\
\text { awareness about the importance of being } \\
\text { obedient with applicable regulations }\end{array}$ & 82 & $96.47 \%$ & Strongly Agree \\
\hline 2. & All decisions are handled by leadership & 81 & $95.29 \%$ & Strongly Agree \\
\hline
\end{tabular}

To directive leadership of questionnaire can be seen above that there are 14 respondents answer strongly agrees (5) and 3 respondents answer agree (4) in the first questionnaire while the second questionnaire shown that there are fourteen answer strongly agree (5), two respondents answer agree and one respondent answers doubt. Thus, both questionnaires show good percent namely $96.47 \%$ and $95.29 \%$. This can concluded that respondent show strongly agree on both questionnaires. To supportive leadership of questionnaire will be drawn the table below:

Table 3. Supportive leadership of questionnaire

\begin{tabular}{|l|l|l|l|l|}
\hline No & Supportive leadership of questionnaire & Score & Percent & Category \\
\hline 1. & $\begin{array}{l}\text { The leader in my place work pays attention to } \\
\text { problems that occur in his employees }\end{array}$ & 69 & $81.17 \%$ & Strongly Agree \\
\hline 2. & $\begin{array}{l}\text { The leader in my place work always gives } \\
\text { solution in employee's problem }\end{array}$ & 84 & $98.82 \%$ & Strongly Agree \\
\hline 3. & $\begin{array}{l}\text { The leader in my place work has ability in } \\
\text { good supervision of employees }\end{array}$ & 65 & $76.47 \%$ & Agree \\
\hline
\end{tabular}

From table above can be concluded that one and two supportive leadership of questionnaire shown strongly agree and number three shows agree. This means that respondent agree and strongly agree with the questionnaire.

Table 4. Participative leadership of questionnaire

\begin{tabular}{|l|l|l|l|l|}
\hline No & Participative leadership of questionnaire & Score & Percent & Category \\
\hline 1. & $\begin{array}{l}\text { The leader in my place work coordinates in } \\
\text { work activity. }\end{array}$ & 79 & $92.94 \%$ & Strongly Agree \\
\hline 2. & $\begin{array}{l}\text { The leader in my place work involves } \\
\text { participation of employee in each activity. }\end{array}$ & 79 & $92.94 \%$ & Strongly Agree \\
\hline 3. & $\begin{array}{l}\text { The leader in my place work accepts } \\
\text { suggestion from his employee in each job }\end{array}$ & 81 & $95.29 \%$ & Strongly Agree \\
\hline 4. & $\begin{array}{l}\text { The leader in my place work is ready to help } \\
\text { and provide solutions in employee's problem }\end{array}$ & 74 & $87.05 \%$ & Strongly Agree \\
\hline
\end{tabular}

The result of table above shown that the first and second questionnaire show 79 score and 92.94 percent which this can be concluded that respondent strongly agrees with the questionnaire. To the third questionnaire gets 81 score where there are fifteen respondents answer strongly agrees and two respondents answer agree. Thus, final questionnaire gets 74 score and $87.05 \%$. These also shown strongly agree. 
Table 5. Leadership Oriented of questionnaire

\begin{tabular}{|l|l|l|l|l|}
\hline No & Leadership oriented of questionnaire & Score & Percent & Category \\
\hline 1. & $\begin{array}{l}\text { The leader in my place work respect and } \\
\text { praise employees wh have good } \\
\text { performance }\end{array}$ & $98.82 \%$ & Strongly Agree \\
\hline 2. & $\begin{array}{l}\text { The leader in my place work always tries to } \\
\text { encourage employees to improve their } \\
\text { abilities }\end{array}$ & $84.70 \%$ & Strongly Agree \\
\hline
\end{tabular}

To both leadership oriented of questionnaire shown strongly agree where the first questionnaire was 84 score and $98.82 \%$, this was caused by sixteen respondents answer strongly agree (5) and one respondent answers agree. Next, thirteen respondents answer agree and four answer strongly agree which mean that both questionnaires shown strongly agree.

Table 6. Employee Performance of questionnaire

\begin{tabular}{|l|l|l|l|l|}
\hline No & Employee Performance of questionnaire & Score & Percent & Category \\
\hline 1. & I am able to work effectively and efficiently & 84 & $98.82 \%$ & Strongly Agree \\
\hline 2. & I was able to finish tasks given well & 84 & $98.82 \%$ & Strongly Agree \\
\hline 3. & I don't do work on time & 20 & $23.52 \%$ & Strongly Agree \\
\hline 4. & $\begin{array}{l}\text { I am able to reach target job in English } \\
\text { Language Education of Department }\end{array}$ & 81 & $95.29 \%$ & Strongly Agree \\
\hline 5. & $\begin{array}{l}\text { I don't like help another employee that feels } \\
\text { difficult }\end{array}$ & 18 & $21.17 \%$ & Strongly Agree \\
\hline
\end{tabular}

Table above explains about employee performance shown that all questionnaires shown strongly agree. From explain above, the writers conclude that the effectiveness of leadership style to employee performance has big influence. This has been seen that almost all respondent in answering questionnaire show strongly agree of category. To be easy understood, the writers make sales below

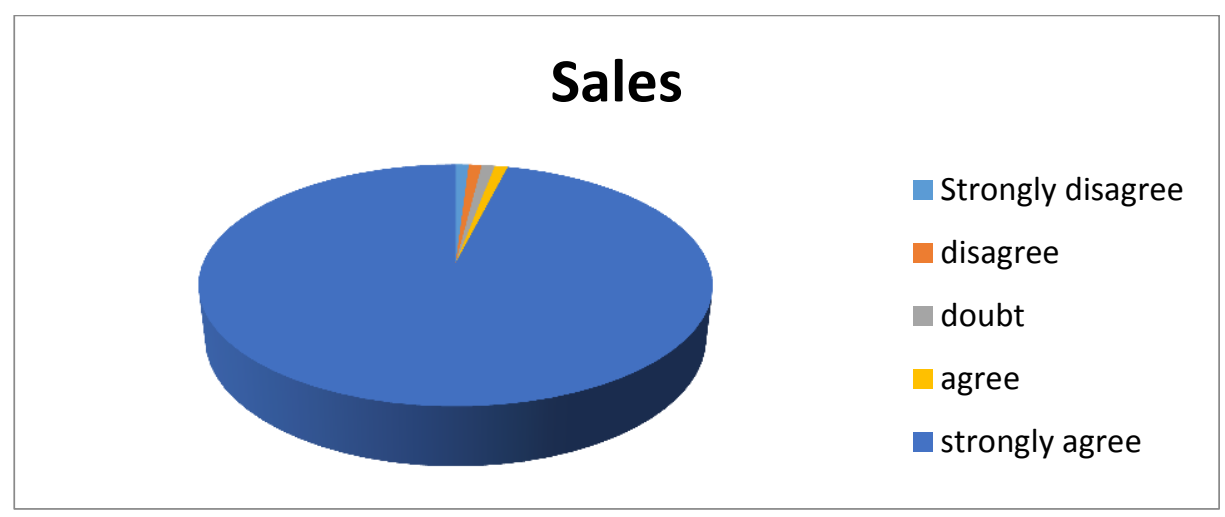

Figure 1. answering questionnaire

\section{CONCLUSION AND SUGGESTION}

\section{Conclusion}

The four variables (leadership style) have an important influence to $\mathrm{Y}$ (employee performance). This can be seen from sales above almost all respondents answer strongly agree of category. This means that leadership style has big influence to employee 
performance in English Education Language Department, State of Islamic (STAIN) Mandaling Natal.

\section{Suggestion}

The implementation of a right leadership style is very influential in order to improve the performance of employees and achieve common goals. The leader should not be easily satisfied with good employee performance results but must also provide encouragement and input so that employee performance increases. The four leadership styles above must continue to be improved and evaluated in order to achieve common goals in English Language Education Department, State of Islamic (STAIN) Mandailing Natal, Panyabungan, North Sumatera, Indonesia.

\section{REFERENCE}

Darmadi, hamid. 2011. Metode Penelitian Pendidikan. Bandung: Alfabeta

Hasibuan, Melayu S.P. 2007. Manajemen Sumber Daya Manusia, Jakarta: PT Bumi Aksara

Mangkunegara, A.A Anwar Prabu. 2000. Manajemen Sumber Daya Manusia. Jakarta: PT Remaja Rosdakarya

Mathis, Robert and Jackson, Jaka H. 2006. Manajemen Sumber Daya Manusia. Jakarta: Salemba Empat.

Sholeha, euis dan Suzy . 1996. Kepemimpinan Yang Effektif Tinjau dan Implementasi bagi Pencapaian Tujuan Organisasi. Jurnal Gema:Stikubank. Hal 45-46

Soekarso, Iskandar Putong, 2015. Kepemimpinan yang efektif dan prktis (volume 1 dari kepemimpinan Edisi 1). Jakarta: Erlangga.

Thoha Miftah. 2013. Kepemimpinan Dalam Manajemen . Jakarta: PT RajaGrafindo

Kartono, Kartini. 2002. Pemimpin dan Kepemimpinan. Jakarta: Rajawali Press

Koesmono, H. Teman.2007. Pengaruh Kepemimpinan Dan Tuntutan Tugas Terhadap Komitmen Organisasi Dengan Variable Moderasi Motivasi Perawat Rumah Sakit Swasta Surabaya. Jurnal manajemen dan kewirausahaab, 9(1). : 300-40

Kreitner, Robert dan Kinick, angelo.2005. Perilaku Organisasi. Jakarta: Salemba Empat Robbins, Stephen. 2007.Manajemen. Jakata:Pt Grafindo

Sugiyono. 2011. Metode Penelitian Kuantitatif, Kualitatif dan R\&D. Bandung: Afabeta Wirawan. 2009. Evaluasi Kinerja Sumber daya Manusia : Teori, Aplikasi, dan Penelitian. Jakarta:Sagung seto 